УДК 331.(65.015.3)

DOI: https://doi.org/10.26642/jen-2019-2(88)-91-97

Н.С. Приймак, к.е.н., доц.

Донецький національний університет економіки і торгівлі ім. М. Туган-Барановського

\title{
Корпоративна культура в системі управління змінами підприємства
}

\begin{abstract}
Актуалізація корпоративної культури у системі управління змінами пов'язана із наступними немаловажними аспектами, які визначають розуміння корпоративної культури у фокусі змін: успіх провадження змін на підприємстві залежить насамперед, від людського фактору змін; в процесі змін організація розглядається як відкрита система; концепція беззупинного розвитку чи усунення процесів стагнації вимагають від системи менеджменту підприємства акиентів на сочаільних чинниках; ринкова орієнтація підприємств та впровадження стратегічних змін вимагають від підприємства застосування стратегічних інструментів управління всіма тактичними та функціональними складовими; в ході впровадження змін акиенти системи менеджменту змін змімуються із матеріальних чинників на нематеріальні; вплив опору на успіх провадження змін в організаиії залежить від його прийнятності в тій чи іншій корпоративній культурі; генерація, розробка та реалізація змін залежать від рівня саморозвитку суб 'єктів змін. У статті визначено зв'язок системи управління змінами підприємства та корпоративної культури, який проявляється у наступних втіленнях останньої: характеристиці соиіальної системи; складовій внутрішнього середовища; продуцента синергійного ефекту змін та їх релевантності иілям, які визначені керівництвом підприємства; чинника використання людського фактору виробництва (впливає на продуктивність праџі, плинність кадрів, рівень абсентеїзму); чинника опору змінам; стратегічного ресурсу. Визначено, що під корпоративною культурою в фокусі управління змінами пропонується розуміти систему иінностей, переконань, вірувань, уявлень, очікувань, символів, а також дієвих принщипів, норм поведінки, традщиій, ритуалів тощсо, які склалися на підприємстві під впливом місї, філософії існування та життєвого ичику організації та визначають досягнення иілей управління змінами. У даному контексті, метою корпоративної культури підприємства можна вважати створення сприятливих умов та формування поведінки персоналу, щь сприяє реалізащії змін. Автором обтрунтовано, щчо ставлення до змін формується на третьому, невидимому, глибинному рівні корпоративної культури, на якому визначається тип реакиії на зміни: підтримка, нейтралітет чи опір змінам. Генерація опору змінам відбувається залежно від підходів до формування корпоративної культури. Згідно даної гіпотези обтрунтовано три рівні опору та рівні корпоративної культури (індивідуальний, груповий та системний).
\end{abstract}

Ключові слова: зміни; управління змінами; опір змінам; корпоративна культура; соціальна система; людський фактор виробництва.

Актуальність теми. Будь-яка ситуація змін та виникнення опору змінам на підприємстві має синергетичний прояв, рівень якого залежить від корпоративної культури підприємства та рівня іiі лояльності до системи управління змінами. Подолання опору змінам можливе тільки в умовах сприятливої корпоративної культури, а тому аспекти її формування та вивчення вимагають особливої уваги науковців та практиків.

Аналіз останніх досліджень та публікації, на які спирається автор. Проблематика корпоративної культури є поширеною серед значного кола науковців до яких можна віднести праці Е. Мейо та У.Уорнера, яких вважають родоначальниками досліджень корпоративної культури; С.Аверинцева, Е.Жеріхова, Д.Ходуса, які вивчають корпоративну культуру з філософської точки зору; Е.Дюркгейма, Л.О. Шемчук, які досліджують корпоративну культуру як соціальне явище; О. В. Тарасової, С.С. Марінової, О.В. Кам'янської, М.І. Копитко, О.В. Харчишиної та ін., які досліджували корпоративну культуру як складову менеджменту підприємства. Проте, вплив корпоративної культури на процеси управління змінами та опору змін, використання корпоративної культури для визначення напрямків подолання опору змінам та формування стратегії змін $є$ недостатньо дослідженими у сучасних наукових публікаціях, а тому, потребують вивчення.

Метою статті $\epsilon$ вивчення місця корпоративної культури в системі управління змінами та особливостей прояву опору змінам на різних рівнях корпоративної культури підприємства.

Викладення основного матеріалу. Професор Корнельского університету (США) Харрісон Трайс зазначив, що першою спробою вивчення діяльності корпорації у культурному аспекті зробила група американських учених на чолі 3 Е. Мейо ще на початку 30x років XX століття при проведенні Хоуторнського експерименту в компанії Western Elektrik, який мав на меті виявити вплив на продуктивність роботи працівників різноманітних факторів [5, с. 68]. Е. Мейо та його найближчий колега

(C) Н.С. Приймак, 2019 
У.Уорнер розробили широку програму дослідження ставлення людей до праці, їхніх принципів та переконань, морального клімату в колективі і т. д., опитавши з цією метою близько 20 тисяч працівників. Саме тому цих учених можна вважати першими дослідниками корпоративної культури, хоча сам термін та концепція 3'явилися значно пізніше. Висновки Е. Мейо щодо необхідності «осмисленого життя для індивідів у компанії», розвитку «почуття групової причетності» на основі загальних колективних цінностей стали поштовхом для подальшого вивчення поведінки працівників з позиції культури їхньої організації [6, с. 23].

Термін «корпоративна культура» вперше використав у XIX ст. у військовій термінології німецький фельдмаршал Мольтке для визначення відносин згуртованості в офіцерському середовищі. На початку XX-го ст. А.Файоль, засновник школи класичного управління, у книзі «Загальне і промислове управління» серед основних принципів управління виокремлює корпоративний дух, розуміючи під ним «згуртованість працівників, єдність сили» [13].

Системні наукові дослідження корпоративної культури розпочалися переважно у 70-80 pp. XX-го ст. На початку нового XXI століття наукові пошуки в цьому напрямі посилилися, що пояснюємо пошуком засобів активізації ролі людського капіталу, забезпечення економічного та інноваційного розвитку підприємств [2, с. 130].

На початку 80-х років XX ст. у теорії управління вперше почали використовувати концепцію корпоративної культури. Масштабні дослідження корпоративної культури у цей період відбувалися у США з метою вивчення особливостей діяльності американських корпорацій. Специфіка полягала в тому, що основу вивчення становила культура кожного з підрозділів корпорацій, які переважно знаходилися в різних географічних регіонах. Саме тому корпоративна культура розглядалася з позиції культури саме корпорацій [7, с. 87].

При визначенні сутності корпоративної культури часто використовують функціональні, психологічні, нормативні та історико-генетичні аспекти. Так, у функціональних визначеннях корпоративної культури описують функції корпоративної культури, її роль як механізму регуляції поведінки між працівниками. Психологічні визначення підкреслюють формування звичок працівників та особливості іх адаптації до організаційного середовища. Описові визначення включають перелік елементів корпоративної культури. Нормативні - звертають увагу на норми й зразки поведінки, історико- генетичні включають до корпоративної культури процеси соціального та культурного наслідування, розвиток традицій, звичаїв, ритуалів [1, с. 69].

Дослідження корпоративної культури сьогодні здійснюють представники різних галузей знань, насамперед філософії, соціології, економіки, культурології та ін. Зокрема у філософії (С.Аверинцев, Е.Жеріхов, Д.Ходус та ін.) корпоративна культура потрактовується як особлива форма організації та адаптації людини.

У соціології одним 3 перших проблематику корпоративізму почав розглядати Е.Дюркгейм. Він розкрив значення корпорації в історичному аспекті та в контексті трактування соціальної солідарності, аналізу регламентації свободи у колективній діяльності. Е.Дюркгейм охарактеризував організаційну культуру як особливу реальність, яка існує об'єктивно, незалежно від індивіда, і чинить на нього примусову дію, регулює його поведінку [12].

Актуалізація корпоративної культури у системі управління змінами пов'язана із наступними немаловажними аспектами, які визначають розуміння корпоративної культури у фокусі змін:

1) успіх провадження змін на підприємстві залежить не стільки від дії зовнішніх чинників змін та ресурсної складової внутрішнього потенціалу змін підприємства, а, насамперед, від людського фактору змін, який просочується у всі складові та ріні системи управління змінами, створюючи їх базисний каркас;

2) в процесі змін організація розглядається як відкрита система, основу якої складають цінності людей (персонал та споживачі кінцевої продукції);

3) концепція беззупинного розвитку чи усунення процесів стагнації вимагають від системи менеджменту підприємства акцентів на соціальних чинниках організаційного дизайну підприємства, які визначають успіх змін та досягнення їх цілей;

4) ринкова орієнтація підприємств та впровадження стратегічних змін вимагають від підприємства застосування стратегічних інструментів управління всіма тактичними та функціональними складовими;

5) в ході впровадження змін акценти системи менеджменту змін зміщуються із матеріальних чинників на нематеріальні, а саме підприємство сприймається як соціально-культурна система, від якої залежить сприйняття змін та їх організаційно-економічний супровід;

6) вплив опору на успіх провадження змін в організації залежить від його прийнятності в тій чи іншій корпоративній культурі;

7) генерація, розробка та реалізація змін залежать від рівня саморозвитку суб’єктів змін, формування i поширення ключових компетенцій, самоменеджменту та використання нормативно-ціннісного, системного та ситуаційного підходів в управлінні змінами. 
Зазначені аспекти формування системи управління змінами доводять єдність та рівнозначність як організаційних та ринкових механізмів провадження змін, так і ціннісних орієнтирів та настановок носіїв людського фактору, задіяних у процесі змін, які визначаються корпоративною культурою.

Місце корпоративної культури в системі управління змінами наведено на рисунку 1.

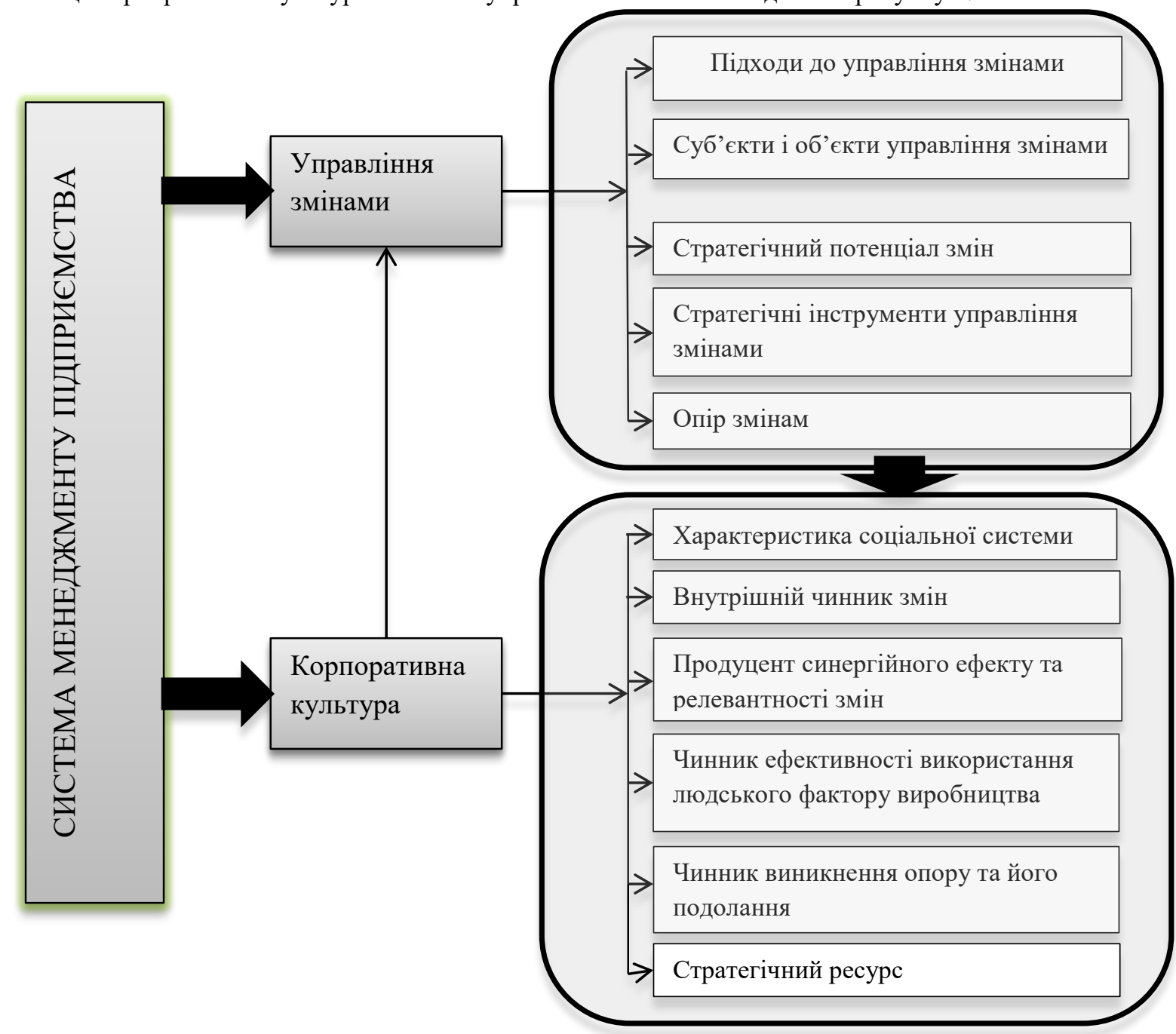

Рис. 1. Місие корпоративної культури в управлінні змінами підприємства (розроблено автором)

Дані рисунка 1 доводять наявність зв'язку між корпоративною культурою та управлінням змінами, який проявляється у впливі корпоративної культури на систему управління змінами підприємства. 3 даним станом речей погоджуються сучасні науковці. Кандидат економічних наук М. І. Чепелюк зазначає, що «рушійною силою реалізації змін виступає корпоративна культура, яка об'єднує підприємство і персонал єдиною філософією, місією, стратегією розвитку, принципами, цінностями, традиціями, створює репутацію в діловому світі, загалом формує власний образ організації, що відрізняє ії від інших [11, с. 258]». Науковець О. Ю. Красовська пише «..за А. Смітом в економіці існує невидимий механізм, що ефективно нею керує, а корпоративна культура - це невидима управлінська рука на підприємстві, яка визначає успішність змін [8, с. 92]». Дослідник О.I. Синицька зазначає, що «у класичному розумінні корпоративна культура розглядається як інструмент стратегічного розвитку компанії через стимулювання інновацій та управління змінами [9, с. 256]».

Отже, зв'язок ключових складових управління змінами (підходів до управління змінами, об'єктів та суб'єктів змін, стратегічного потенціалу змін, стратегічних інструментів змін та опору змінам) із корпоративною культурою підприємства проявляється у наступних втіленнях останньої:

- характеристиці соціальної системи - існування корпоративної культури можливе тільки в рамках соціальної системи, оскільки носієм культури є людський фактор;

- складовій внутрішнього середовища, а значить корпоративна культура може вважатися внутрішнім фактором змін; 
- продуцента синергійного ефекту змін та їх релевантності цілям, які визначені керівництвом підприємства. Для корпоративної культури підприємства у фокусі управління змінами сприяння змінам має викликати позитивний ефект, тобто синергію змін. Опір змінам сприймається як дисергія;

- чинника використання людського фактору виробництва (впливає на продуктивність праці, плинність кадрів, рівень абсентеїзму);

- чинника опору змінам - корпоративна культура виступає у двоєдиній ролі: одночасно визначає причини опору змінам на індивідуальному, груповому та системному рівнях та напрямки його усунення;

- стратегічного ресурсу - корпоративна культура у сучасному менеджменті сприймається як стратегічний інструмент, спрямований на встановлення ефективних комунікацій між рівнями менеджменту та досягненням за рахунок цього стратегічних цілей організації.

Корпоративна культура підприємства виникає в момент його створення та існує у будь-якій компанії, незалежно від іiі розмірів, видів діяльності, форми власності тощо. Вона має внутрішню орієнтацію, але при цьому зовнішні агенти підприємства можуть фіксувати іiі особливості. Вона проявляється у організаційній поведінці персоналу та розвивається синхронно із еволюцією персоналу та його ставлення до місії, цілей, стратегії та інструментів іії реалізації.

Враховуючи наведене вище, під корпоративною культурою в фокусі управління змінами пропонується розуміти систему цінностей, переконань, вірувань, уявлень, очікувань, символів, а також дієвих принципів, норм поведінки, традицій, ритуалів тощо, які склалися на підприємстві під впливом місії, філософії існування та життєвого циклу організації та визначають досягнення цілей управління змінами. У даному контексті, метою корпоративної культури підприємства можна вважати створення сприятливих умов та формування поведінки персоналу, що сприяє реалізації змін.

Завдання корпоративної культури в системі управління змінами зводяться до наступного:

- створення соціально-психологічного клімату та атмосфери сприяння (лояльності) змінам;

- забезпечення адекватної поведінки в контексті ставлення до змін;

- мотивування персоналу до спільної та успішної діяльності в процесі змін;

- розвиток у персоналу почуття причетності до змін;

- створення атмосфери причетності та «занурення у зміни»;

- підтримка індивідуальної ініціативи суб’єктів змін;

- справедливе делегування відповідальності за зміни та їх наслідки;

- стабільність соціальних відносин;

- підтримка індивідуальної ініціативи носіїв, стейкхолдерів та агентів змін;

- зміцнення корпоративної родини за рахунок успішної реалізації змін.

Елементи корпоративної культури - це сукупність цінностей та норм.

Ядром корпоративної культури є цінності. Соціальні, моральні і культурні цінності створюють в єдності корпоративну культуру суспільства загалом й окремих організацій зокрема. На їх основі виробляються норми і форми поведінки людини. Саме вони формують модель поведінки і спілкування в організації, внутрішньо-організаційні норми і соціальні ролі.

Під нормами розуміємо узагальнені правила, що керують поведінкою працівників і приводять їх до досягнення цілей організації. Ролі визначають внесок кожного у спільну діяльність, залежно від позиції (формальної або неформальної), яку займає в організації, а також взаємні очікування і взаємний контроль працівників [10, с. 30-31]

Саме цінності, які панують в компанії визначають ставлення до змін та підходи до управління змінами, тоді як норми визначають прояв ставлення та видовий прояв опру змінам.

В умовах функціонування підприємства як відкритої соціально-економічної системи, корпоративна культура в системі управління змінами виконує ряд функцій, а саме:

1) інтегративну - забезпечує імплементацію робітника чи окремої їх групи у процес змін. Дана функція культури пов'язані із існуванням феномену «занурення у зміни» які забезпечує робітнику так званий «ефект причетності» до змін, дає йому можливість відчути себе частиною команди змін, або навпаки частиною течії з протистояння змінам;

2) адаптаційну - забезпечує пристосування робітника через сукупність соціальних та організаційних (формальних і неформальних) зв'язків до умов змін;

3) комунікативну - доведення потоків інформації щодо сутності змін та оціночних суджень про них до робітників чи їх груп за допомогою прийнятних на підприємстві форм передачі інформації та комунікаційних каналів;

4) регулятивну - формування та регулювання необхідних форм поведінки, відбраковування тих поведінкових форм, що не відповідають змісту даної культури, ії цінностям та нормам. У контексті змін дана функція проявляється у позитивному підкріпленні бажаної реакції на зміни;

5) акумулювання спільної пам'яті що досвіду впровадження змін та подолання опору;

6) амбівалентність - одночасна підтримка декількох видів цінностей. 
Сучасні науковці [3, с. 39; 10 ], які займаються дослідженням корпоративної культури, наголошують, що змістовний аспект корпоративної культури прослідковується через іїі рівні.

Перший рівень - видимий, базисний, отримав назву «артефакти культури». Він формує основу моделей поведінки людського фактору в колективі, його відношення до реалізації виробничих процесів. На цьому рівні відображаються правила поведінки персоналу, манера вдягатися, символи та організаційні церемонії, особливості розташування офісів, тобто все те, що дозволяє спостерігати за поведінкою як менеджерів так і виконавців.

Другий рівень - невидимий, змістовний, який характеризує результат роботи людського фактору 3 урахуванням здобутків першого рівня та відображає їхні цінності, що культивуються у процесі роботи. Причому, виявляється, є певна частка цінностей, які закладені у півсвідомості носіїв людського фактору, хоча їх не помічають, але вони керують поведінкою людського фактору у процесі формування та реалізації управлінських рішень.

Третій рівень - невидимий, глибинний. На цьому рівні відбувається прояв особистісних психологічних цінностей, які були сформовані і закладені раніше: мислення, почуття та волю. Однак саме ці цінності, спрямовують носіїв людського фактору на досягнення об'єктивного блага відповідно до трьох сфер духовності - пізнання, мистецтво, мораль [3, с. 39-40]».

Узагальнення рівнів прояву корпоративної культури, та врахування природи опору змінам, автором сформовано модель ставлення суб'єктів змін до змін та управління змінами на різних рівнях корпоративної культури. Визначено, що ставлення до змін формується на третьому, невидимому, глибинному рівні корпоративної культури, на якому визначається тип реакції на зміни: підтримка, нейтралітет чи опір змінам (узагальнено автором на рис. 2).

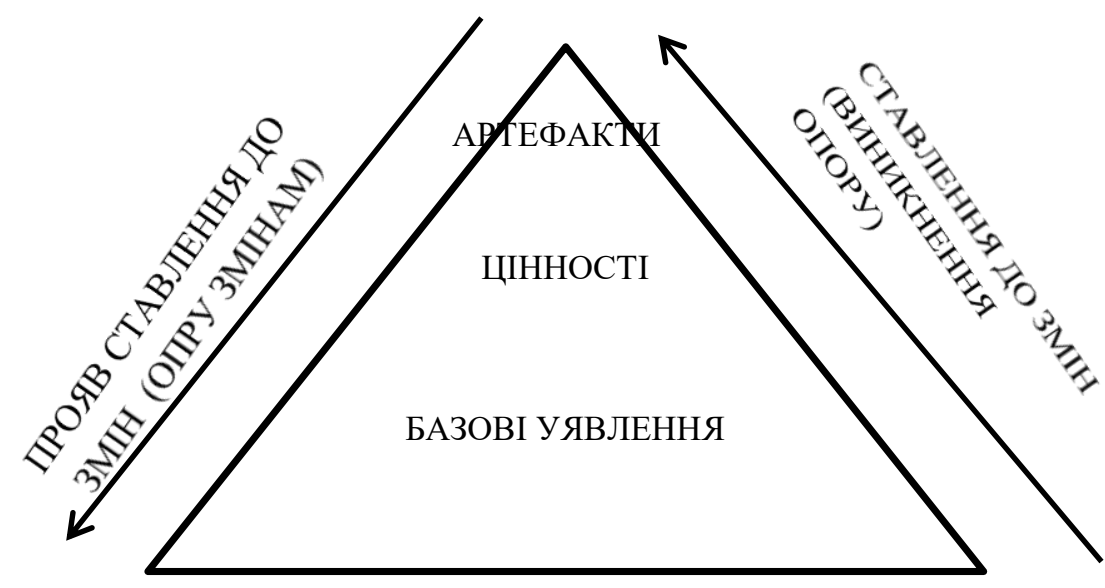
Рис. 2. Ставлення суб'єктів змін до змін та управління змінами
на різних рівнях корпоративної культури (складено автором)

У випадку виникнення опору, його генерація від індивідуального до системного відбувається 3 третього до першого рівнів корпоративної культури. При цьому, реакція та прояв ставлення до змін і управління змінами на третьому та другому рівнях $\epsilon$ прихованою, на першому рівні $\epsilon$ явною, декларованою.

Типологія прояву опору змінам на підприємстві тісно пов'язана із рівнями корпоративної культури (артефакти, цінності, базові уявлення), оскільки визначає природу виникнення такого опору та його демонстраційність на підприємстві (табл. 1).

Дані таблиці 1 демонструють складний характер виникнення типів опору, який має коріння переважно на другому (ціннісному) та третьому (рівні базових уявлень) рівнях корпоративної культури. Прояв опору на рівні артефактів $є$ крайньою мірою прояву опору змінам на підприємстві.

Виникнення опору змінам є складним процесом, прояв якого можна дослідити, використовуючи концепцію корпоративної культури, запропоновану науковцем Л. Смірсіч, провідним фахівцем у галузі організаційних змін, та розвинену В.Л. Гевко. Концепція корпоративної культури, відповідно до підходу Л. Смірсіча, передбачає розгляд останньої відповідно трьох аспектів: як незалежної складової, внесеної в організацію ззовні; як внутрішньої складової організації; як суті організації [14, с. 342]. Відповідно до першого підходу корпоративна культура розглядається як система уявлень, цінностей та соціальних і економічних взаємозв'язків, які формує в людині суспільство. Другий підхід полягає у розумінні корпоративної культури як системи правил, цінностей та ритуалів, що є спільними для усіх працівників. Третій підхід характеризує корпоративну культуру як концептуальну сутність організації, що визначає загальну систему цінностей підприємства [4, с.11]. 
Зв’язок типології прояву опру змінам та рівнів корпоративної культури (складено автором)

\begin{tabular}{|c|c|c|c|c|c|c|c|c|c|}
\hline \multirow[b]{2}{*}{ Рівень корпоративної культури } & \multicolumn{9}{|c|}{ Тип прояву опору змінам } \\
\hline & 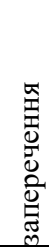 & 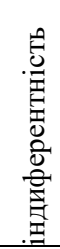 & 至 & 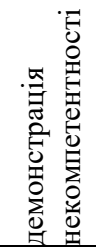 & 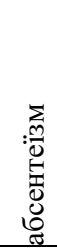 & 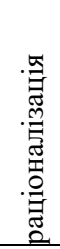 & 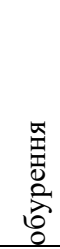 & 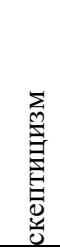 & . \\
\hline $\begin{array}{lcr}\text { Перший } & \text { рівень } \quad- & \text { видимий, } \\
\begin{array}{l}\text { базисний, } \\
\text { «артефакти культури» }\end{array} & \text { назву } \\
\text { «аримав } & \end{array}$ & + & & & + & + & + & + & & \\
\hline $\begin{array}{lccc}\text { Другий рівень } & - & \text { невидимий } \\
\text { характеризує цінності } & \\
\end{array}$ & & + & + & & & & & + & + \\
\hline $\begin{array}{l}\text { Третій рівень - невидимий, } \\
\text { глибинний, базові уявлення }\end{array}$ & + & & & & & & + & & + \\
\hline
\end{tabular}

Генерація опору залежно від підходів до формування корпоративної культури наведена на рисунку 3.

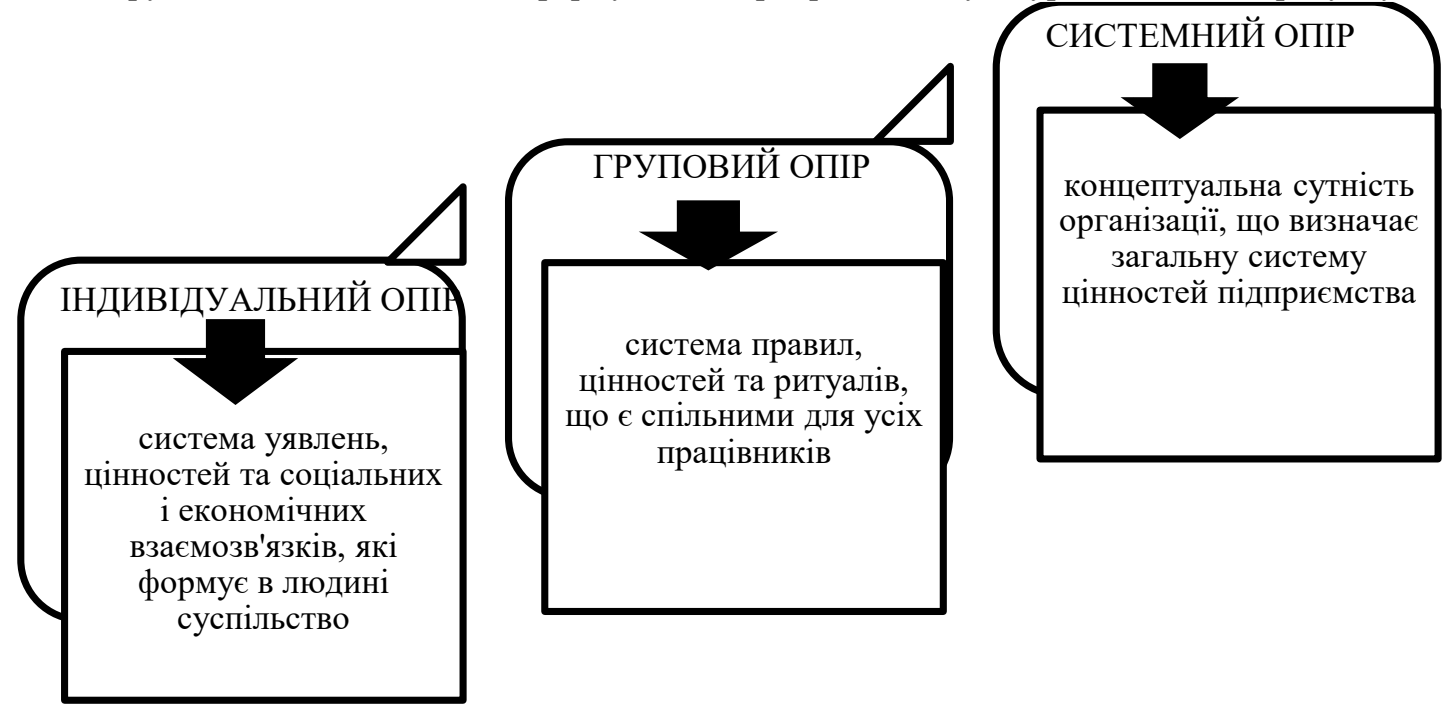

Рис. 3. Генерація опору змінам рівнями корпоративної культури підприємства (складено автором на основі $[4,13])$

Наведені на рисунку 3 рівні опору та рівні корпоративної культури доводять взаємообумовленість даних процесів та ступеневий характер виникнення опору. Проте, індивідуальний, груповий та системний опір, як наслідки породження різних рівнів корпоративної культури не є взаємовиключними та не переходять один в одного у загальній кремації опору змінам.

Висновки та перспективи подалыших досліджень. Використання запропонованого підходу до розуміння корпоративної культури як інтегрованої складової управління змінами дозволить забезпечити системі менеджменту змін на підприємстві ефективне управління опором на всіх стадіях та рівнях його виникнення.

\section{Список використаної літератури:}

1. Апостолюк $O$. Корпоративна культура як інструмент ефективного менеджменту підприємства в підвищенні його конкурентоспроможності / О.Апостолюк // Економічний часопис Східноєвропейського національного університету імені Лесі Українки. - 2016. - № 2. - С. 68-73.

2. Беляк Т.О. Корпоративна культура: доцільність якісних змін з урахуванням пріоритетів інноваційного розвитку / Т.О. Беляк // Вісник Чернівецького торговельно-економічного інституту. Серія : Економічні науки. 2014. - Вип. 4. - С. 129-136. - URL : http://nbuv.gov.ua/UJRN/Vchtei_2014_4_16.

3. Виноградова O.B. Корпоративна культура як стратегічний інструмент в системі управління телекомунікаційними підприємствами / О.В. Виноградова, Н.О. Свтушенко // Економіка. Менеджмент. Бізнес. - 2016. - № 4. - C. 38-44. - URL : http://nbuv.gov.ua/UJRN/ecmebi_2016_4_7.

4. Гевко В.Л. Організаційна культура підприємства та особливості і умови ï зміни / В.Л. Гевко // Інвестиції: практика та досвід. - 2018. - № 16. - URL : http://www.investplan.com.ua/pdf/16_2018/4.pdf.

5. Захарченко В.И. Экономический механизм процесса нововведений : учеб. пособие / В.И. Захарченко ; под ред. И.П. Продиуса. - Одесса : «АОЗТ ИРЗНТиТ», 2005. - 450 с.

6. Кам'янська О.В. Корпоративна культура в системі управління інноваційним підприємством / О.В. Кам'янська // Економіка та держава. - 2010. - № 8. - C. 23-24. - URL : http://nbuv.gov.ua/UJRN/ecde_2010_8_7. 
7. Копитко M.I. Корпоративна культура підприємств: історія виникнення та сутність / M.I. Копитко // Причорноморські економічні студії. - 2016. - Вип. 9 (1). - С. 86-91.

8. Красовська О.Ю. Генезис поняття «корпоративна культура підприємства» / О.Ю. Красовська // Економічний вісник Запорізької державної інженерної академії. - 2017. - Вип. 6 (1). - С. 89-93.

9. Синицька O.I. Корпоративна культура: типологізація, функції та критерії забезпечення у формуванні соціально-трудових відносин на ринку праці України / O.I. Синищька // Науковий вісник Херсонського державного університету. Серія : Економічні науки. - 2014. - Вип. 5 (3). - С. 255-261.

10. Тарасова O.B. Корпоративна культура як інструмент ефективного менеджменту підприємства / О.В. Тарасова, С.С. Марінова // Економіка харчової промисловості. - 2013. - № 3. - С. $28-32$.

11. Чепелюк M.I. Роль корпоративної культури підприємства в концепціях організаційних змін / M.I. Чепелюк // Проблеми формування та реалізації конкурентної політики : матеріали III Міжнар. наук.-практ. конф., м. Львів, 19-20 верес. 2013 р. / Національний університет «Львівська політехніка» [та інші]. - Львів : АртDрук, 2013. - C. 258-259.

12. Шемчук Л.О. Корпоративна культура як предмет наукових досліджень / Л.О. Шемчук // Наукові записки Вінницького державного педагогічного університету імені Михайла Коцюбинського. Серія : Педагогіка і психологія. - 2013. - Вип. 40. - С. 133-137.

13. Файоль А. Общее и промышленное управление / Анри Файоль ; пер. с фр. Б.В. Бабина-Кореня. - М., 1923. [Электронный ресурс]. - Режим доступа : http://gtmarket.ru/laboratory/basis/5783.

14. Smircich L. Concept of culture and organizational analysis / L.Smircich // Administrative Science Quaterly, Jeffrey Sonnenfeld. - 1983. - Vol. 28. - pp. 339-358.

\section{References:}

1. Apostoljuk, O. (2016), «Korporatyvna kul'tura jak instrument efektyvnogo menedzhmentu pidpryjemstva v pidvyshhenni jogo konkurentospromozhnosti», Ekonomichnyj chasopys Shidnojevropejs'kogo nacional'nogo universytetu imeni Lesi Ukrai'nky, No. 2, pp. 68-73.

2. Beljak, T.O. (2014), «Korporatyvna kul'tura: docil'nist' jakisnyh zmin z urahuvannjam priorytetiv innovacijnogo rozvytku», Visnyk Chernivec'kogo torgovel'no-ekonomichnogo instytutu, Ekonomichni nauky, Issue 4, pp. 129-136, URL: http://nbuv.gov.ua/UJRN/Vchtei_2014_4_16

3. Vynogradova, O.V. and Jevtushenko, N.O. (2016), «Korporatyvna kul'tura jak strategichnyj instrument v systemi upravlinnja telekomunikacijnymy pidpryjemstvamy», Ekonomika. Menedzhment. Biznes, No. 4, pp. 38-44, URL: http://nbuv.gov.ua/UJRN/ecmebi_2016_4_7

4. Gevko, V.L. (2018), «Organizacijna kul'tura pidpryjemstva ta osoblyvosti i umovy i'i' zminy», Investycii': praktyka ta dosvid, No. 16, URL: http://www.investplan.com.ua/pdf/16_2018/4.pdf

5. Zaharchenko, V.I. (2005), Jekonomicheskij mehanizm processa novovvedenij, in Prodiusa, I.P. (ed), AOZT IRZNTiT, Odessa, $450 \mathrm{p}$.

6. Kam'jans'ka, O.V. (2010), «Korporatyvna kul'tura v systemi upravlinnja innovacijnym pidpryjemstvom», Ekonomika ta derzhava, No. 8, pp. 23-24, URL : http://nbuv.gov.ua/UJRN/ecde_2010_8_7

7. Kopytko, M.I. (2016), «Korporatyvna kul'tura pidpryjemstv: istorija vynyknennja ta sutnist'», Prychornomors'ki ekonomichni studii', Issue 9 (1), pp. 86-91.

8. Krasovs'ka, O.Ju. (2017), «Genezys ponjattja «korporatyvna kul'tura pidpryjemstva», Ekonomichnyj visnyk Zaporiz'koi' derzhavnoi' inzhenernoi' akademii', Issue 6 (1), pp. 89-93.

9. Synyc'ka, O.I. (2014), «Korporatyvna kul'tura: typologizacija, funkcii' ta kryterii' zabezpechennja u formuvanni social'no-trudovyh vidnosyn na rynku praci Ukrai'ny», Naukovyj visnyk Hersons'kogo derzhavnogo universytetu, Serija Ekonomichni nauky, Issue 5 (3), pp. 255-261.

10. Tarasova, O.V. and Marinova, O.V. (2013), «Korporatyvna kul'tura jak instrument efektyvnogo menedzhmentu pidpryjemstva», Ekonomika harchovoi' promyslovosti, No. 3, pp. 28-32.

11. Chepeljuk, M.I. (2013), «Rol' korporatyvnoi' kul'tury pidpryjemstva v koncepcijah organizacijnyh zmin», Problemy formuvannja ta realizacii' konkurentnoi' polityky, materialy III Mizhnar. nauk.-prakt. konf., m. L'viv, 19-20 veres. 2013 r., Nacional'nyj universytet «L'vivs'ka politehnika» [ta inshi], ArtDruk, L'viv, pp. 258-259.

12. Shemchuk, L.O. (2013), «Korporatyvna kul'tura jak predmet naukovyh doslidzhen'», Naukovi zapysky Vinnyc'kogo derzhavnogo pedagogichnogo universytetu imeni Myhajla Kocjubyns'kogo, Serija Pedagogika i psyhologija, Vyp. 40, pp. 133-137.

13. Fayol, H. (1923), Administration Industrielle et Générale, Translated by Babyna-Korenja, B.V., Moskva, [Online], available at: http://gtmarket.ru/laboratory/basis/5783

14. Smircich, L. (1983), «Concept of culture and organizational analysis», Administrative Science Quaterly, Vol. 28, pp. 339-358.

Приймак Наталія Сергіївна - кандидат економічних наук, доцент, завідувач кафедри маркетингу, менеджменту та публічного адміністрування, Донецький національний університет економіки і торгівлі ім. М. Туган-Барановського.

Наукові інтереси:

- управління змінами;

- амортизаційна політика;

- стратегічне управління. 